\title{
THE JOURNAL OF MENTAL SCIENCE
}




\title{
THE JOURNAL
}

\section{$\mathrm{OF}$ \\ MENTAL SCIENCE,}

nublished by the Authority of the

\section{ASSOCIATION OF MEDICAL OFFICERS OF ASYLUMS AND HOSPITALS FOR THE INSANE:}

\author{
EDITED BY \\ JOHN CHARLES BUCKNILL, M.D.
}

\section{VOLUME V.}

LONDON :

LONGMAN, GREEN, LONGMAN \& ROBERTS. 1859. 
IXETER:

PRINTED BX WILLIAM POLLARD, NORTH STREET. 


\section{INDEX TO VOLUME V.}

Annual Meeting of Association of Medical Officers of Asylums and Hospitals for the Insane . $\quad$. 56

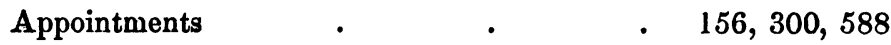
Association of Medical Officers of Asylums and Hospitals

for the Insane, Special Meeting of _ . 373 Atkinson, James, Prison Letters of $\quad$. 430 Baths in the Treatment of Insanity, by H. Tuke, M.D. . 102 Bran Bread, Efficacy of, in Melancholia . . 408 Browne, Dr., last Report on Crichton Asylum $\quad$. 200 Boyd, Robert, M.D., On the Necessity of Insanity as a Branch of Medical Education . $\quad$. $\quad$ - 573 Bucknill, John Charles, M.D, on Hamlet . 1

\begin{tabular}{|c|c|c|c|}
\hline " & $"$ & on Reports of English Asylums & - 157 \\
\hline " & $"$ & on Reports of Scotch Asylums & 200 \\
\hline " & $"$ & on Reports of Irish Asylums & 218 \\
\hline$"$ & $"$ & \multirow{2}{*}{\multicolumn{2}{|c|}{$\begin{array}{l}\text { on Reports of East Indian Asylums } \\
\text { on Report of Commissioners of In- } \\
\text { quiry on the state of Lunatic } \\
\text { Asylums in Ireland, \&c., \&c. }\end{array}$}} \\
\hline " & $"$ & & \\
\hline$"$ & $"$ & $\begin{array}{l}\text { on Observations on the Report } \\
\text { the Commissioners of Inquiry intc } \\
\text { Lunatic Asylums in Ireland, by } \\
\text { J. Nugent, M.D., Inspector } \\
\text { Lunatic Asylums }\end{array}$ & $\begin{array}{l}\text { of } \\
\text { to } \\
\text { of } \\
\text { of } \\
\text { - } 222\end{array}$ \\
\hline ", & $"$ & on King Lear & . 301 \\
\hline$"$ & $"$ & on Lunacy Reform & . 421 \\
\hline ', & 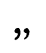 & on Irish Lunacy Legislation & - 435 \\
\hline & $"$ & on Michelet's "Love" . & . 349 \\
\hline & & 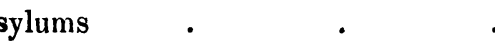 & 227 \\
\hline
\end{tabular}


vi.

Commentaries on Insanity, by D. F. Tyerman, Esq. $\quad 366,585$

Commissioners in Lunacy, Twelfth Report of • 245

" Supplement to Twelfth Report of $\quad$. 547

Commissioners in Lunacy, Scotland, First Report of $\quad$. 445

Conolly, John, M.D., on Residences for the Insane . 411

Conolly; Edward T., Esq., on Suggestions for Amendments of the Law Relating to Private Lunatic Asylums 297

Corrigan, Dr., on Visiting Physicians • • • 435

Davey, Dr., on the Relations between Crime and Insanity 82

Discussion upon Dr. Tuke's Paper, on the Diagnosis of

General Paralysis . $\quad$ • $\quad$ • $\quad$ • 78

Expectancy of Life in the Insane . . 280

Excerpta from the Evidence given before the Select Committee of the House of Commons on Iunatics 482

General Paralysis, Essay on, by Dr. Harrington Tuke 78, 575

Ganglionic Nervous System, by Dr. Davey .

Hamlet, a Psychological Study . $\quad$.

Huxley, Dr., on the Existing Relation between the Lunacy

Commission, and Medical Superintendents of Public

$\begin{array}{llllll}\text { Asylums } & \cdot & \bullet & \bullet & \bullet & 95\end{array}$

Jacobi, Dr., Obituary Notice of • • • 289

Instructions of Scotch Commissioners on Building Asylums 478

Inquisition of Lunacy on Mrs. Turner $\quad$. $\quad 114$

" $"$ on Mr. Ruck $\quad$ • . 122

Irish Asylums, Reports of $\quad$. $\quad$. $\quad$. 215

\# Proposed Legislation, on . . . 435

Irregularity of the Pupils from Central Causes, by Dr.

Palmer . $\quad . \quad 2 \quad$. . $\quad .286$

Laws relating to Private Lunatic Asylums, Suggestions $\begin{array}{llll}\text { for Amendments of . } & \text {. } & \text { • } & \text {. } 297\end{array}$

Lear, A Psychological Study $\quad$. $\quad$. $\quad$. 301

L'Amour, par J. Michelet . . $\quad$. 349

Legislation on Irish Lunatic Asylums $\quad . \quad \quad 435$

Lunacy Law Reform . $\quad$. $\quad$. $\quad$. 421

Morningside Asylum, Visit of Association to . . 101

Notes on Prognosis in Mental Disease, by C. L.

Robertson, M.B. $\quad$ • $\quad$ • $\quad$ • $\quad$. 257 
Necessity of Insanity as a Branch of Medical Education, by Robert Boyd, M.D. ․ . $\quad$. $\quad 573$

Object and Distribution of Asylum Reports . 159

Observations on the Report of the Commissioners of Inquiry into Lunatic Asylums in Ireland, by J. Nugent, M.D.

Officers of Association, Election of

Official Report of the Special General Meeting of the Association of Medical Officers of Asylums and Hospitals for the Insane .

Opium Eating of Lincolnshire Peasantry $\quad$ • 173

Plans of Irish Asylums $\quad$ • $\quad$ • $\quad$. 229

Poorhouses, Lunatics in the Scotch $\quad . \quad$. 465

President's Address . $\quad$. $\quad$. $\quad$. 71

Private Lunatic Asylums, Newspaper Attack on $\quad$. 146

Prognosis in Mental Disease, Notes on . $\quad 257$

Proposed Legislation on Irish Lunatic Asylums, The . 437

Reflex Muscular Action in General Paralysis, Note by

Dr. Bucknill

Report of Committee of Association on the Lunacy Bills 440

Reports of Lunatic Asylums ․ . $\quad$. 157

Report of the Commissioners of Inquiry on the state of Lunatic Asylums, \&c., in Ireland

Report of the Commissioners in Lunacy to the Lord Chancellor

Report of the General Board of Commissioners in Lunacy for Scotland

Residences for the Insane, by Dr. Conolly . . . 411

Robertson, C. L., M.D., on Notes on Prognosis in Mental Disease

" $\quad$ on Report of Commissioners in Lunacy for Scotland

Sea-side Residences for the Insane.

Shaftesbury, Earl of, Evidence of

Skae, Dr., on General Paralysis .

Statistics of Asylum Reports

- 220

Statistics of Scotch Asylums

- 472 
viii.

Index.

Suggestions for Amendments of the Laws relating to Private Lunatic Asylums, by Edward T. Conolly, Esq. 297 Supplement to the Twelfth Report of the Commissioners in Lunacy

- 547

Treasurer's Report $\quad . \quad$. $\quad$. $\quad$. 69

Tuke, Harrington, M.D., on Warm and Cold Baths in the Treatment of Insanity . 102 , $\quad$ on General Paralysis 78, 375

Twelfth Report of the Commissioners in Lunacy • 245

Tyerman, D. F., Esq., Commentaries on Insanity 366, 585

Visiting Physicians to Asylums . $\quad$. 241

Workhouses, Detention of Lunatic Paupers in 175 